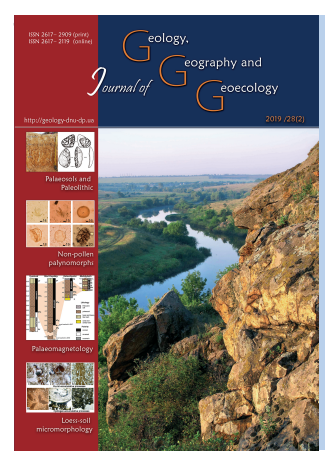

D.V. Hlavatskyi

\section{Journal of Geology. Geography and Geoecology}

Journal home page: geology-dnu-dp.ua
ISSN 2617-2909 (print)

ISSN 2617-2119 (online)

Journ.Geol.Geograph. Geology, 28(2), 301-312. doi: $10.15421 / 111930$

\title{
Refined magnetostratigraphic position of the Shyrokyne unit in loess sequences from Central Ukraine
}

\author{
D.V. Hlavatskyi \\ Institute of Geophysics of National Academy of Sciences of Ukraine, Kyiv, Ukraine. e-mail: hlavatskyi@gmail.com
}

Received: 31.01 .2019

Received in revised form: 10.04 .2019

Accepted: 16.04.2019

Abstract. The youngest geomagnetic polarity reversal, the Matuyama-Brunhes boundary (MBB), which occurred $780 \mathrm{kyr}$ ago, is a "golden spike" in the age calibration of sediment sequences. The use of palaeomagnetic method as a stratigraphic tool in the study of loess sequences from Ukraine originated some 50 years ago. One major problem in using the available data is the contradictory position of the MBB in different stratigraphic units, which affected historic evolution of the chronostratigraphic models of the Quaternary in Ukraine. The most important units in this regard are the Shyrokyne and Martonosha units, in which the MBB had been defined most often. This paper provides the careful analysis of the previous magnetostratigraphic data and new preliminary results from key loess-palaeosol sections in Central Ukraine. Shyrokyne palaeosol complex in four loesspalaeosol sections located in the Middle Dnieper and Podolia regions has been palaeomagnetically studied. It is shown that the transition zone of the Matuyama-Brunhes palaeomagnetic reversal is most likely located at the base of the soil complex. In the Vyazivok section the MBB has been found in the lowermost part of Shyrokyne palaeosol sh. Preliminary palaeomagnetic studies of the Stari Kaydaky section reveal that the MBB cannot be defined at least above $\mathrm{sh}_{1}$ subunit. Medzhybizh and Holovchyntsi sections were deposited after the Matuyama-Brunhes reversal; however, the palaeomagnetic informativeness of the part of studied strata is doubtful. Magnetostratigraphic position of the Shyrokyne unit below the MBB in some previous studies is explained by methodological reasons and inconsistent chronostratigraphic models. The paper substantiates that normal magnetic polarity zone in the Pryazovya loess and upper part of the Shyrokyne soil is not associated with the influence of secondary processes on the palaeomagnetic record.

Key words: magnetostratigraphy, Matuyama-Brunhes boundary, palaeomagnetic method, loess-palaeosol sequence, Pleistocene, marine isotope stage 19.

\section{Уточнене магнітостратиграфічне положення широкинського горизонту у лесових серіях Центральної України}

\author{
Д.В. Главацький \\ Інститут геофізики Націіональної академї̈ наук України, Київ, Україна, е-таil: hlavatskyi@gmail.com
}

Анотація. Наймолодша геомагнітна інверсія полярності, границя Матуяма-Брюнес (МБ), що відбулася 780 тис. р. тому, $є$ «золотим цвяхом» у віковому калібруванні осадових серій. Використання палеомагнітного методу як стратиграфічного інструменту при дослідженні лесових серій України бере початок близько 50 років тому. Однією з головних проблем використання наявних даних $є$ суперечливе положення границі МБ у різних стратиграфічних горизонтах, що позначилося на історичному розвитку хронотратиграфічних моделей четвертинного періоду в Україні. Найбільш важливими підрозділами у цьому контексті $є$ широкинський та мартоноський горизонти, в яких границя МБ визначалася найчастіше. У цій статті проведено ретельний аналіз попередніх магнітостратиграфічних даних та нових попередніх результатів ключових лесово-грунтових розрізів у Центральній Україні. Широкинський грунтовий комплекс досліджено палеомагнітним методом у чотирьох лесовогрунтових розрізах, що знаходяться у Середньому Придніпров’ї та на Подільській височині. Показано, що перехідна зона палеомагнітної інверсії Матуяма-Брюнес найімовірніше розташована у підошві грунтового комплексу. У розрізі В'язівок границю МБ було знайдено у нижній частині широкинського грунту sh. Попередні палеомагнітні дослідження розрізу Старі Кайдаки свідчать про те, що границя МБ не може бути визначена принаймні вище підгоризонту sh. Відклади розрізів Меджибіж і Головчинці сформувалися після інверсії Матуяма-Брюнес; однак, палеомагнітна інформативність частини досліджених шарів сумнівна. Магнітостратиграфічне положення широкинського горизонту нижче границі МБ у деяких попередніх робо- 
тах пояснюється методологічними причинами та непослідовними хроностратиграфічними моделями. У статті обгрунтовано, що зона прямої полярності у приазовському лесі та широкинському грунті не пов'язана із впливом вторинних процесів на палеомагнітний запис.

Ключові слова: магнітостртиграфія, граниия Матуяма-Брюнес, палеомагнітний метод, лесово-грунтова серія, плейстоцен, морська ізотопна стадія 19.

Introduction. Loess sequences, alternating loess and palaeosol horizons, are unique continental formations of the Quaternary. They contain one of the most complete records of global changes in the climate of this geological period, in particular, glaciations and interglaciations of the last million years, and are significantly widespread, mostly at intermediate latitudes of the Northern Hemisphere (Evans and Heller, 2003; Buggle, 2011). For this reason, loess sediments are carefully studied by various methods of environmental research, including the palaeomagnetic method.

The Matuyama-Brunhes polarity reversal, which occurred $780 \mathrm{kyr}$ ago (Tauxe et al., 1996) is the key benchmark of correlation of loess-palaeosol sequences of the Quaternary, defining the LowerMiddle Pleistocene boundary. In deep-sea sediments, this reversal is fixed in the interglacial marine isotope stage (MIS) 19 (Tauxe et al., 1996).

Loess-palaeosol exposures along Dnieper, Sula and Southern Bug rivers in Central Ukraine reveal a complexsuccessionofQuaternary palaeoenvironments over the past 0.7-1.2 million years (Veklich, 1982; Bolikhovskaya and Molodkov, 2006; Matviishyna et al., 2010; Buggle, 2011). For magnetologists the most important unit in the loess sequences is the Shyrokyne horizon (hereinafter the stratigraphic terminology is used in accord with the Stratigraphic Framework of the Pleistocene of Ukraine (Veklich et al., 1993)) - palaeosol complex consisting of three subunits: brown clayey soils of earlier optimum $\mathrm{sh}_{1}$ and later optimum $\mathrm{sh}_{3}$, and uncommon loess-like loam subunit $\mathrm{sh}_{2}$ (Gozhik and Gerasimenko, 2011; Sirenko, 2017). Previously the Matuyama-Brunhes transition zone was defined by colleagues from the Institute of Geophysics (Tretyak et al., 1987; Tretyak et al., 1989; Tretyak and Vigilyanskaya, 1994; Vigilyanskaya, 2000, 2001a, 2001b, 2002) in wide range of sections most often in the lowermost $\mathrm{sh}_{1}$ subunit. According to their generalized Pleistocene Magnetostratigraphic Scale of Ukraine (Tretyak and Vigilyanskaya, 1994), which is based on the palaeomagnetic studies of almost 60 sections in Ukraine, Moldavia and Pryazovya, the Matuyama-Brunhes boundary (MBB) is located in the Shyrokyne horizon (according to stratigraphic nomenclature of (Veklich et al., 1984)), the age of which was estimated at $730 \mathrm{kyr}$. Thus, the Shyrokyne unit should be evidently correlated with MIS 19 (Bogucki et al., 2012).
However, in the stratigraphic models, which are proposed for the Ukrainian Quaternary, the chronological placement of the Shyrokyne unit is different. It is generally argued that this pedocomplex and the respective interglaciation occurred during 0.85-1.2 Ma (Matviishyna et al., 2010) and corresponds to MIS 25 (Veklich, 1995, cited in Bolikhovskaya and Molodkov, 2006) or 21-33 (Lindner et al., 2006). Therefore, the younger Martonosha palaeosol unit is placed either in MIS 19-23 (Veklich, 1995, cited in Bolikhovskaya and Molodkov, 2006) or 17-19 (Lindner et al., 2006). Theoretical correlation with marine oxygen isotope stages of stratigraphic schemes of Ukraine, resulting from the different opinions on the chronological placement of the Shyrokyne and Martonosha units, is given in (Bakhmutov et al., 2017).

The above frameworks are based in turn on initial contradictory magnetostratigraphic data (Tretyak and Volok, 1976; Tretyak, 1980, 1983; Tretyak et al., 1980, 1986; Veklich, 1982), in which the MBB had been defined in the Berezan, Shyrokyne, Martonosha, Sula and Lubny units. Eventually, the normal polarity zone within Przyazovya loess and the upper part of the Shyrokyne soil units had been interpreted by geologists as Jaramillo event ( $0.98 \mathrm{Ma})$ and the MBB had been placed at the top of the Martonosha soil unit, which became the basis for following palaeogeographic reconstructions (Veklich, 1987; Lindner et al., 2004; Lindner et al., 2006; Matviishyna et al., 2010; Gozhik and Gerasimenko, 2011 and others). However when considering them, surprising unanimity in position of the MBB in several key Pleistocene sections is troubling. For example in (Lindner et al., 2004, fig. 2) the MBB in the Vyazivok section had been defined based on only one sample with anomalous polarity at the base of Sula loess (Veklich, 1982, fig. 26), and in the Roxolany section (Lindner et al., 2004, fig. 3) - one sample of reversed polarity in Martonosha soil (Tretyak, 1980, fig. 1; Tretyak, 1983, fig. 6.5). It should be recognized that most of previous results (Tretyak and Volok, 1976; Tretyak, 1980, 1983; Tretyak et al., 1980, 1986; Veklich, 1982; Veklich, 1987), carried out without effective minimization the acquisition of present-day viscous magnetization, and defined abundant magnetic events therein, cannot be taken as reliable as any stratigraphic correlations based in them (Bakhmutov and Hlavatskyi, 2016). 
However, later in several sections of Southern Ukraine and Ukrainian Shield the MBB was found exactly at Martonosha horizon level (Bakhmutov et al., 2005; Sirenko et al., 2008; Slivinskaya et al., 2012), which supports the existing charts. In addition, in the Roxolany section, one of the key loess sequences of the Black Sea area, the MBB was defined recently at the contact of two soils (Bakhmutov and Hlavatskyi, 2014a, b), which were stratified by (Gozhik et al., 2007; Bogucki et al., 2013) as the Lubny and Martonosha units.

In order to resolve the problem of inconsistency between different stratigraphic positions of the MBB in loess cover of Ukraine, the most complete sections of the Quaternary should be investigated. In this study initial results, focusing on determination the MBB in key loess-palaeosol sequences of the Middle Dnieper area at Vyazivok and Stari Kaydaky are given. Additionally, new results of palaeomagnetic study of the Podolian Upland sequences - the Lower Palaeolithic sites - at Medzhybizh and Holovchyntsi are presented.

Geological setting. The Vyazivok section is located in the village of Vyazivok $\left(49^{\circ} 33^{\prime} \mathrm{N}, 32^{\circ} 98^{\prime} \mathrm{E}\right)$ about $8 \mathrm{~km}$ south of Lubny of Poltava oblast on the western bank of the Sula River, a tributary of the Dnieper (Fig. 1). It represents one of the most complete Quaternary records in Ukraine and the longest section studied within Dnieper Lowland. It is characterized by 59 -meter sequence of several well developed palaeosols which alternate with thick loess units. The section was studied earlier by (Veklitch et al., 1967; Matviishyna et al., 2001; Rousseau et al., 2001). The detailed description of the section which the author was guided in rock sampling is presented in (Matviishyna et al., 2001). The Shyrokyne unit in the Vyazivok section is represented by two subunits. The lower subunit $\mathrm{sh}_{1}$, which is $1.15 \mathrm{~m}$ thick, consists of two substages: greyish-brown clayey soil $\mathrm{sh}_{1 \mathrm{~b} 1}$ and reddish-brown sandy-clayey soil $\mathrm{sh}_{1 \mathrm{~b} 2}$. The upper soil subunit $\mathrm{sh}_{3}$, which is $2.35 \mathrm{~m}$ thick, is chocolate-brown soil, composed of clay, more compact, prismatic, with abundant carbonate concretions at the base of soil.

The Stari Kaydaky (or Stari Kodaky) section $\left(48^{\circ} 22^{\prime} \mathrm{N}, 35^{\circ} 07^{\prime} \mathrm{E}\right)$ is located south of Dnipro at the Dnieper River. The sequence comprises eight major loess-palaeosol couples. It was stratified by (Veklich and Sirenko, 1972) and was declared as reference Pleistocene section of Ukraine. The uppermost part of the section (from the Lubny unit to the Holocene unit) had been studied in particular by rock magnetic methods (Buggle et al., 2008, 2009, Buggle, 2011) and it was correlated with loess sequences of Danube basin. The Shyrokyne unit in studied exposure at Stari Kaydaky is not less than $8 \mathrm{~m}$ thick, which is almost twice as much its thickness in the stratotype sequence at Shyrokyne (4.5 m) (Veklich and Sirenko, 1972). It includes three subunits: subunit $\mathrm{sh}_{1}$, which is at the minimum $3.9 \mathrm{~m}$ thick, subunit $\mathrm{sh}_{2}(0.55 \mathrm{~m}$ thick $)$ and the upper soil $\mathrm{sh}_{3}\left(3.6 \mathrm{~m}\right.$ thick). The lower subunit $\mathrm{sh}_{1}$

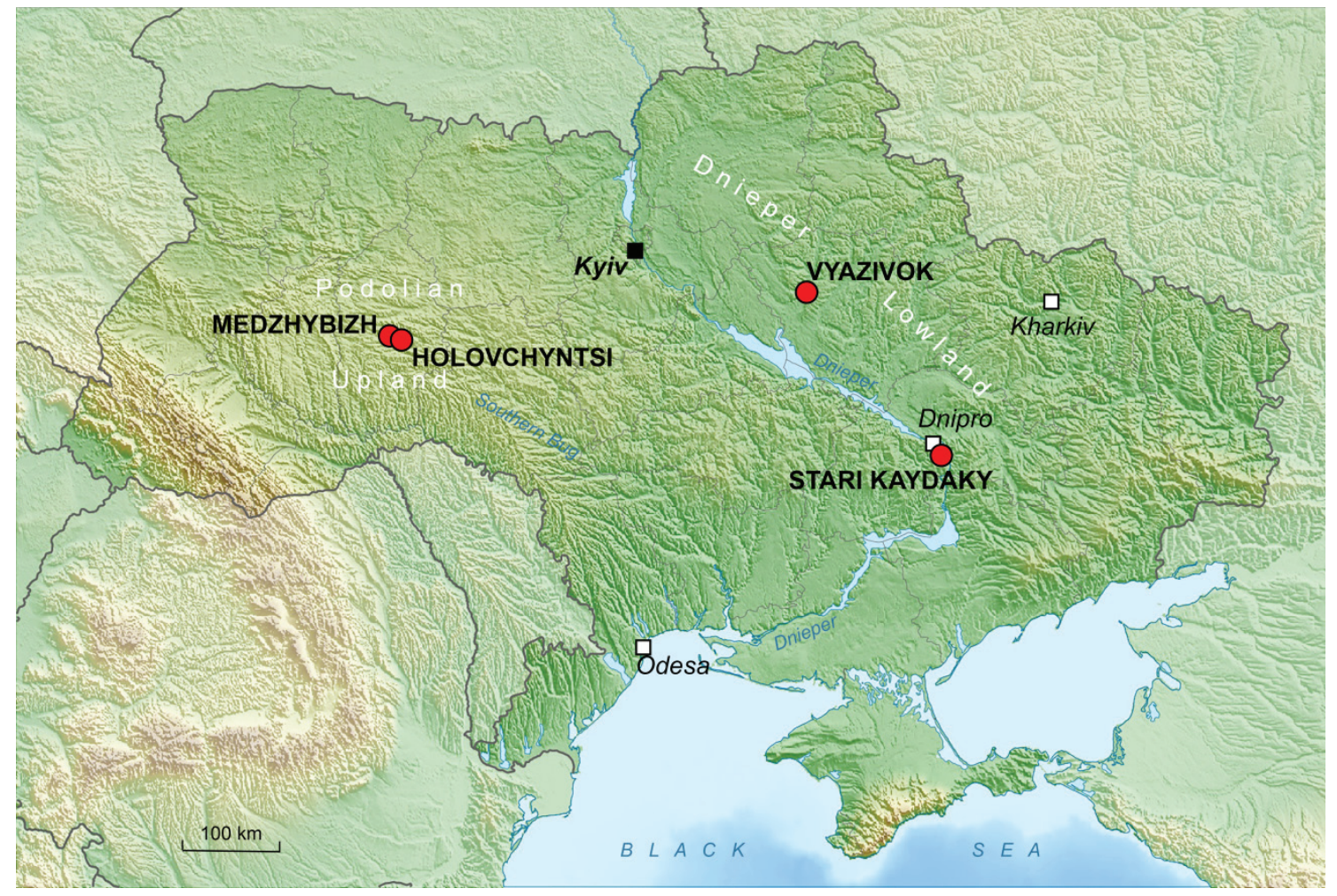

Fig. 1. Location of studied sections on the map of Ukraine. 
consists of the solid chocolate-brown soil, composed of clay, compacted, prismatic, with rare carbonate concretions at the base of soil, and the upper dark humus subhorizon. The middle subunit $\mathrm{sh}_{2}$ includes thin reddish-brown loam and dark humus layer. The upper subunit $\mathrm{sh}_{3}$ is brown clayey soil.

The Medzhybizh-A section $\left(49^{\circ} 25^{\prime} \mathrm{N}, 27^{\circ} 23^{\prime}\right.$ E) is located in the village of Medzhybizh about 33 $\mathrm{km}$ east of Khmelnytskyi on the nothern bank of the River Southern Bug. Loess sequence covers the time interval from the Shyrokyne unit to the Holocene, and lies on the marine sediments of the Sarmatian time (Stepanchuk et al., 2014). It is famous archaeological site of the Lower Palaeolithic. Archaeological artifacts were found in the palaeosols of the Zavadivka, Lubny, Martonosha and Shyrokyne stratigraphic units (Stepanchuk et al., 2014, 2016). The Shyrokyne horizon is very thin (a few tens of centimeters) and is composed of sandy clay.

The Holovchyntsi-1 section $\left(49^{\circ} 25^{\prime} \mathrm{E}, 2^{\circ} 29^{\prime} \mathrm{N}\right)$ is located $1.3 \mathrm{~km}$ north of the village of Holovchyntsi and $7.5 \mathrm{~km}$ east of Medzhybizh-A section on the northern bank of the River Southern Bug. The section is the southern part of the current Holovchynskyi granite quarry. It was investigated by archaeologists from the Lower Palaeolithic expedition of the Institute of Archeology of the National Academy of Sciences of Ukraine in cooperation with geologists (Yu.M. Veklich, S.P. Karmazinenko, A.V. Nadvirnyak) for the first time in 2015. Initially, studied soil horizons, which are $3 \mathrm{~m}$ thick, were attributed by geologists to the Zavadivka or Lubny unit. Conclusions based on topography and stratigraphy of the location, as well as artifact typologies, clearly indicated the discovery of a new Lower Palaeolithic location in the region (Vetrov, 2016). Research was continued in 2016-2017 under the guidance of V.N. Stepanchuk. According to new stratigraphic interpretation of Zh.M. Matviyishina and S.P. Karmazinenko the palaeosols were already stratified as the Shyrokyne horizon and it was possible to establish a preliminary conclusion about the oldest artifacts found in Ukraine - 0.9-1.2 Ma. The interpretation of stratigraphic subdivision by Zh.M. Matviyishina and S.P. Karmazinenko has been used in this paper.

Sampling and methods. Samples for palaeomagnetic studies in the Vyazivok section have been collected in 2014-2015. 173 oriented rectangular blocks were taken from the whole sequence, which were cut into 692 oriented cubes with an edge of $2.0 \mathrm{~cm}$. Samples from Shyrokyne horizon have been processed in 2014 from 2 exposures (Zupynka 1 and Zupynka 2) which represent the same units of the Lower Pleistocene.

In 2015 a total of 81 blocks were taken from the
Medzybizh-A section and in 2017 - 17 blocks from the Holovchyntsi-1 section. Considering the loose state of the oriented rectangular blocks selected in the Medzhybizh-A section, it was not possible to make stable cube samples for magnetometric measurements. It was possible to make only a few oriented samples mostly from the lowermost part of the section.

Samples from Shyrokyne palaeosol in the Stari Kaydaky section have been collected over two field seasons during 2017-2018. It was difficult to reach the primary exposure because of a thick deluvium layer. 26 oriented rectangular blocks were taken. For now 65 oriented cubes from the uppermost part were cut from 11 rectangular blocks, taken in 2017. Sampling density is about every $10-20 \mathrm{~cm}$.

Palaeomagnetic measurements were carried out in the laboratory of the Institute of Geophysics of the National Academy of Sciences of Ukraine (Kyiv). Partly the measurements were performed in the laboratories of Palaeomagnetism Department of the Institute of Geophysics of the Polish Academy of Sciences (Warsaw) and The Ivar Giæver Geomagnetic Laboratory hosted by the Centre for Earth Evolution and Dynamics at the University of Oslo (Oslo).

The natural remanent magnetisation (NRM) was measured using JR-6, JR-6A magnetometers and SQIUD $2 \mathrm{G}$ Enterprises magnetometer accompanied by an alternating field demagnetizer. All samples were subjected to stepwise thermal demagnetization (THD) up to $240-350^{\circ} \mathrm{C}$ and alternating field demagnetization (AFD) in fields of up to $100 \mathrm{mT}$. All measurements have been performed inside the magnetically shielded rooms to minimize the acquisition of present-day viscous magnetization.

Directions of characteristic remanent magnetization (ChRM) component has been calculated by multicomponent analysis of the demagnetization path (Kirschvink, 1980), using Remasoft 3.0 software (Chadima and Hrouda, 2006). Polarity zones were built in MPS program (Man, 2008).

Brief overview of previous results and new preliminary data. Vyazivok section. Previously the Vyazivok profile had been palaeomagnetically studied in the 1970's (Veklich, 1982). In one sample at the lowermost level of the Sula loess (the samples below were not selected) anomalous polarity had been established. It was announced that the MBB lies at the top of the Martonosha palaeosol, and it had long been thought that the Martonosha unit belongs to Matuyama chron. This conclusion was the basis for futher correlation charts of the Quaternary in Ukraine and neighboring territories (Lindner et al., 2004).

The whole sequence had been studied by (Vigilyanskaya, 2001b; composite palaeomagnetic 
section is in fig. 9 in (Matviishyna et al., 2001)). 233 samples were thermally demagnetized up to $250^{\circ} \mathrm{C}$ and 132 samples were demagnetized by alternating field up to $50 \mathrm{mT}$. The MBB was clearly defined in Shyrokyne palaeosol.

Preliminary results of palaeomagnetic and rock magnetic study of the Vyazivok section were published by author of this study with co-authors in (Hlavatskyi et al., 2016b). Most of the samples from the Shyrokyne unit and surrounding Pryazovya and Illichivsk loess units containe a high-coercivity component, removed totally only by $80-100 \mathrm{mT}$ field demagnetization. In some cases it could not be destroyed even by $100 \mathrm{mT}$ alternating field or $300^{\circ} \mathrm{C}$ temperature. According to thermomagnetic analysis the main carriers of NRM in studied rocks are magnetite and hematite. Paramagnetic minerals also play a significant role in the magnetic properties of this loess-palaeosol sequence (Hlavatskyi et al., 2016b).

Samples demagnetized by alternating field and temperature have similar positive inclination and northerly declination values for the depth interval $51.5-56.2 \mathrm{~m}$. Only in two specimens above 56.2 $\mathrm{m}$ (from upper part of the Shyrokyne unit), which were thermally demagnetized, was a full reversal of directions observed. Other samples keep steady inclinations in average at $66^{\circ}$. However, data from samples below suggest a major polarity change at a depth of $56.2 \mathrm{~m}$ which is interpreted as evidence of the Matuyama-Brunhes polarity boundary. Samples below this level have mean ChRM inclination direction $-52^{\circ}$ and declination direction $181^{\circ}$. The Jaramillo subchron cannot be identified in the Vyazivok section.

Thus, the MBB was found at a depth of approximately $56.2 \mathrm{~m}$ in the lowermost Shyrokyne soil $\mathrm{sh}_{1}$. After removal of viscous component, loess and soil samples display the presence of a stable hard component carried mainly by hematite.

Stari Kaydaky section. For the first time the Stari Kaydaky section was studied by A.N. Tretyak and L.I. Vigilyanskaya and the MBB was determined in the Shyrokyne palaeosol (V.G. Bakhmutov and N.P. Gerasimenko, personal communication, 2018). But any publications of A.N. Tretyak and L.I. Vigilyanskaya concerning palaeomagnetic research of the Stari Kaydaky profile cannot be found in the Institute of Geophysics library filing cabinet, as there are no appropriate references in their works. Only composite palaeomagnetic section is available. Probably, this section was studied before 1994, because Stari Kaydaky outcrop is marked as studied section on the map, attached to Pleistocene Magnetostratigraphic scale of Ukraine (Tretyak and Vigilyanskaya, 1994).
Preliminary investigations by V.G. Bakhmutov in 2006 (personal communication, 2018), in which high precision measurement equipment (including 2G Enterprises magnetometers) had been used, could not detect the geomagnetic polarity change of the MBB. The studied part of the profile included interval from the top of the Shyrokyne unit (uppermost part with a thickness of $1.5 \mathrm{~m}$ ) to the Holocene soil. In all layers, including top of $\mathrm{sh}_{3}$ subunit as the overlying Pryazovya loess and Martonosha palaeosol units, exceptionally normal polarity was observed.

Works on demagnetization of samples of the lowermost layers are currently in progress. For now, a pilot collection of 24 specimens from the entire thickness of the $\mathrm{sh}_{3}$ and $\mathrm{sh}_{2}$ subunits, and from upper humus subhorizon of $\mathrm{sh}_{1}$ subunit have been treated by temperature up to $300^{\circ} \mathrm{C}$. Since most of the specimens were fragile, they cannot be heated to temperatures above $300^{\circ} \mathrm{C}$ and few steps of demagnetization at temperatures $210,240,270$ and $300^{\circ} \mathrm{C}$ have been carried out. After stepwise THD objectively one stable component is observed on the orthogonal vector diagrams (Fig. 2a,b), which is not totally removed by temperature of $300^{\circ} \mathrm{C}$. Probably the secondary component overprint was demagnetized at temperatures lower than $210^{\circ} \mathrm{C}$, but incomplete demagnetization also is possible. In most samples the component, which was accepted as characteristic, decays linearly towards the origin, with only normal directions indicating the formation of studied subunits during the Brunhes chron.

Average value of bulk magnetic susceptibility is $310 \times 10^{-6}$ unit SI, which is the same as in the Shyrokyne unit of the Vyazivok section $\left(318 \times 10^{-6}\right.$ unit SI). These values indicate typical for loess-palaeosol series of Ukraine concentration of magnetic minerals.

Full details of the further palaeomagnetic data from the Stari Kaydaky section require a separate paper and will be presented in future submissions.

\section{Medzhybizh and Holovchyntsi sections.}

Complex rock magnetic and palaeomagnetic studies of the Medzhybizh-A and Holovchyntsi-1 loesspalaeosol sections for the first time were performed by (Bakhmutov et al., 2018) in order to determine the suitability of these objects for palaeomagnetic study and the establishment of magnetostratigraphic markers.

The deposits of the Medzhybizh-A and Holovchyntsi- 1 sections are characterized by low values of magnetic susceptibility, which indicates an insignificant content of magnetic minerals, especially in the Medzhybizh-A section (in average $82 \times 10^{-9} \mathrm{~m}^{3} /$ $\mathrm{kg}$, in contrast to $178 \times 10^{-9} \mathrm{~m}^{3} / \mathrm{kg}$ in the Holovchyntsi section, Fig. 3). Investigated sections by rock mag- 

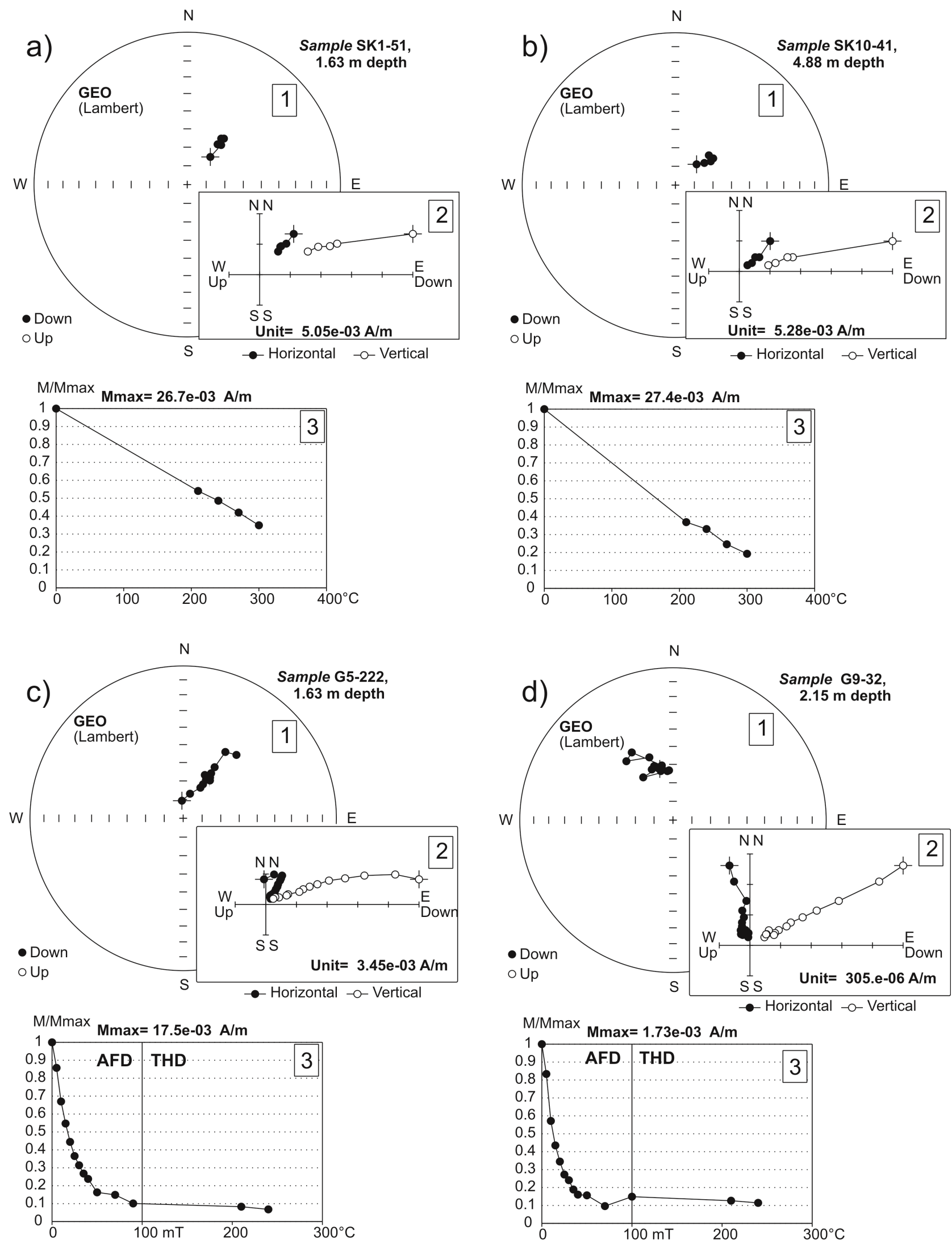

Fig. 2. Examples of stepwise thermal (a, b) demagnetization of soil samples from the Shyrokyne unit in the Stari Kaydaky section, and alternating field and following thermal (c, d) demagnetization of soil samples from the Shyrokyne unit in the Holovchyntsi-1 section.

1 - stereographic projections of demagnetization directions, 2 - orthogonal demagnetization projections, 3 - intensity decay curves of NRM. 
netic characteristics are closest to the sections of the Volynian Upland, and refer to the intermediate "Chinese" type of formation of magnetic properties with an admixture of the "Alaskan" mechanism (Hlavatskyi et al., 2016a; Bakhmutov et al, 2017).

Most of the samples from both sections have visually disturbed texture, which is confirmed by anomalous data on the anisotropy of the magnetic susceptibility. In interpretation of (Bakhmutov et al., 2018), it reflects the orientation of ferrimagnetic grains due to currents, slope processes, winds etc. Samples, in which the primary magnetic texture is not broken, were selected for further laboratory palaeomagnetic studies.

In order to determine characteristic component of NRM a pilot collection of the samples from both sections has been demagnetized by stepwise AFD up to $100 \mathrm{mT}$ (using cryogenic SQUID magnetometer 2G Enterprises with an in-line alternating field demagnetizer), and THD up to $240-350^{\circ} \mathrm{C}$. Most of the samples show ChRM directions of normal polarity (Fig. 2c, d). Below the soil horizon $\mathrm{sh}_{3}$ in the Holovchyntsi-1 section the NRM and ChRM values decrease in average to $1 \times 10^{-3} \mathrm{~mA} / \mathrm{m}$ and $0.5 \times 10^{-3} \mathrm{~mA} / \mathrm{m}$, respectively (Fig. 3), and the samples show a large scatter of the ChRM directions with predominantly anomalous polarity.

Taking into account the secondary changes in the deposits, the minimum values of the remanent magnetization in the soil, the small thickness of the section as a whole, it is not possible to reliably determine the primary component of the magnetization in the deposits within the lowermost layers. Statistical characteristics of NRM and ChRM after demagnetization by magnetic field and temperature are shown in fig. 3 in (Bakhmutov et al., 2018). The average values for the directions of the NRM and ChRM components within $\mathrm{sh}_{3}$ subunit agree within $95 \%$ and $99 \%$ confidence limits and indicate a direction close to the current geomagnetic field in the area (Fig. 3).

The results of palaeomagnetic studies turned out to be uninformative for the most layers of the Medzhybizh-A section and for the lowermost part of the Holovchyntsi-1 section ( $\mathrm{sh}_{1}$ subunit) because of

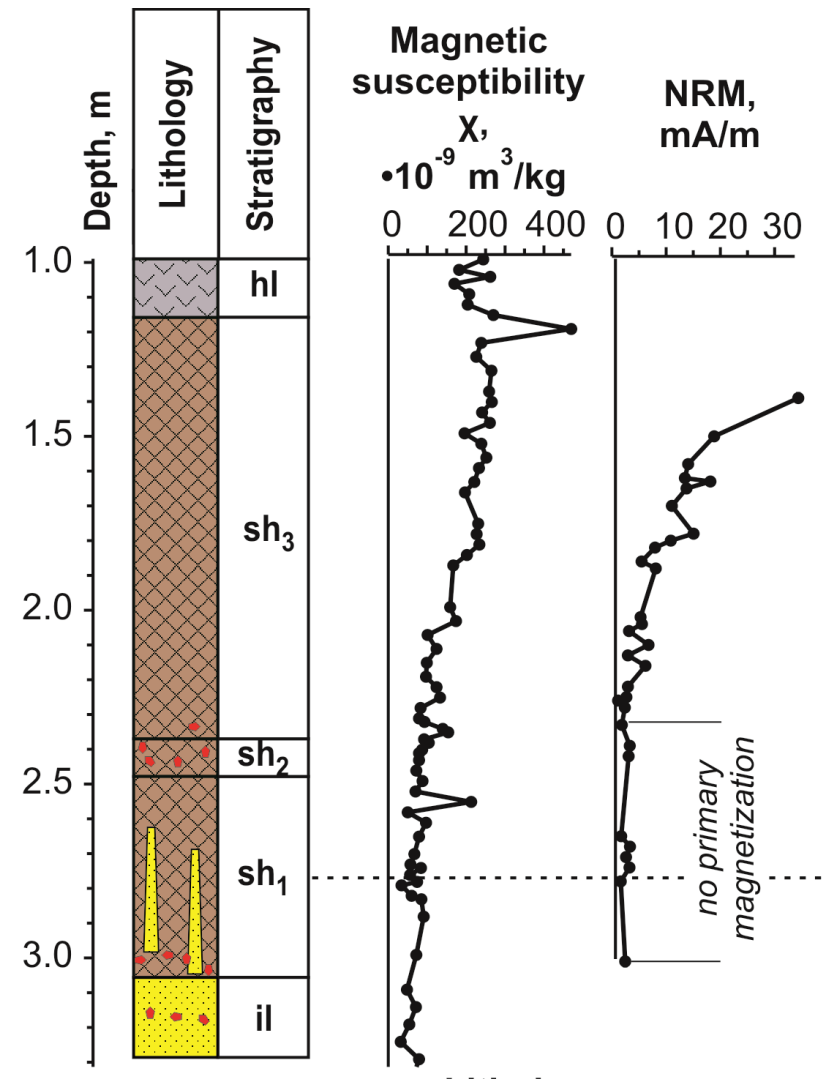

Lithology
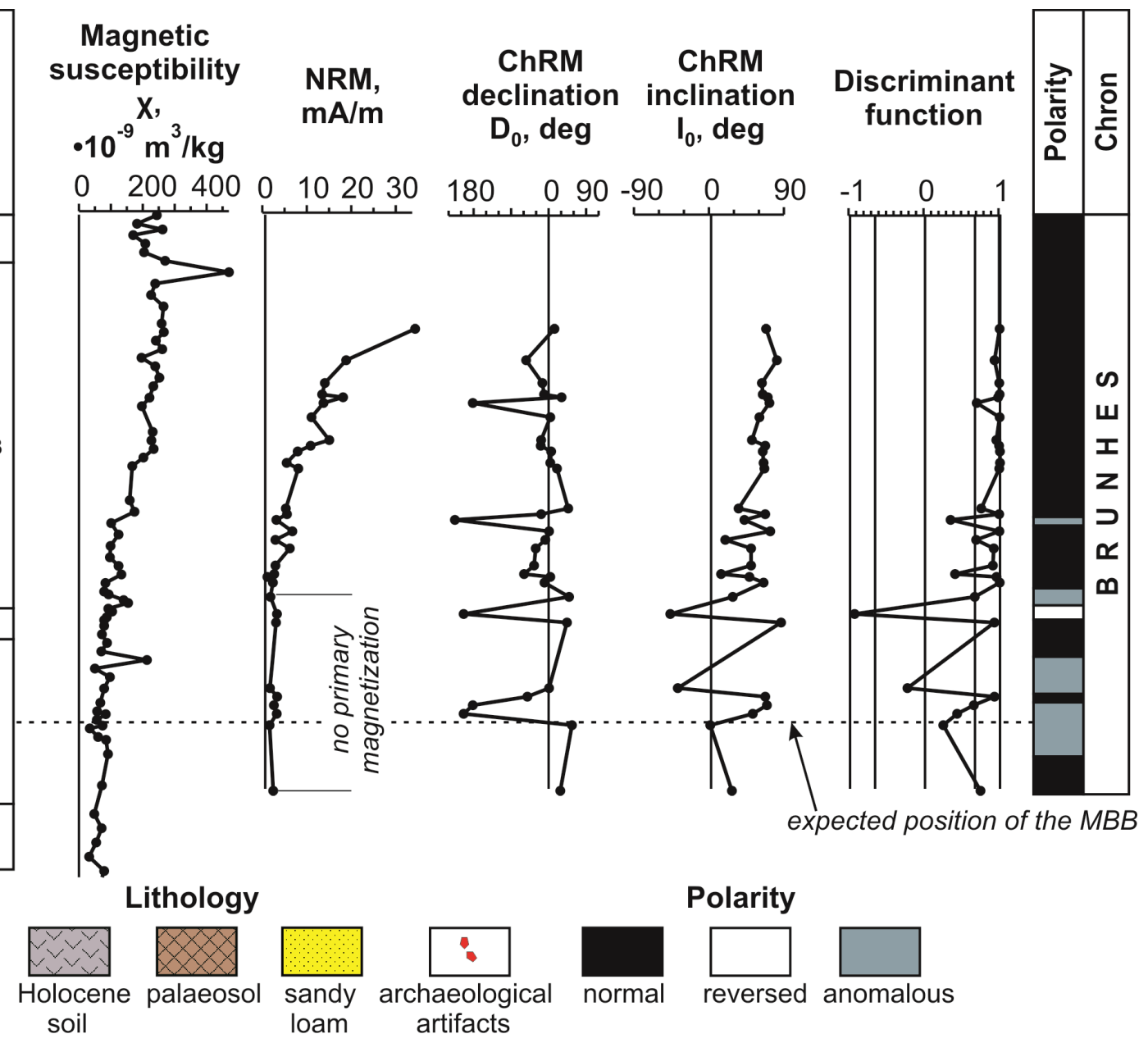

Polarity

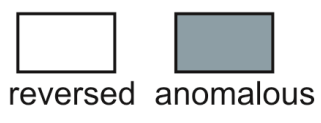

Fig. 3. Results of palaeomagnetic study of the Holovchyntsi-1 section: lithostratigraphy (Matviishyna and Karmazinenko, 2017), magnetic susceptibility, normal remanent magnetization, ChRM directions, discriminant function and palaeomagnetic chart. 
the almost complete absence of ferrimagnetic material and the disturbance of the sedimentary magnetic texture of the rocks. The entire loess-soil stratum of the Medzhybizh section according to preliminary data can be attributed to the Brunhes chron, i.e. the age of the rocks in the section does not exceed $780 \mathrm{kyr}$. In the Holovchyntsi-1 section the Matuyama-Brunhes boundary also was not clearly identified. The polarity is reliably allocated only in the upper soil $\mathrm{sh}_{3}$.

Discussion. Preliminary palaeomagnetic data obtained in key Pleistocene sections of the Middle Dnieper region in contrast to most of current palaeogeographic reconstructions (Veklich, 1995 cited in Bolikhovskaya and Molodkov, 2006; Matviishyna et al., 2010; Gozhik and Gerasimenko, 2011) and in agreement with the earlier conclusions in (Tretyak and Vigilyanskaya, 1994; Vigilyanskaya, 2001a, b) and the latter correlation model (Bogucki et al., 2012) manifest the position of the MBB in the lowermost part of the Shyrokyne pedocomplex. In the Vyazivok section the MBB was found in the Shyrokyne palaeosol subunit $\mathrm{sh}_{1}$, which is in full agreement with previous data, obtained by Vigilyanskaya (2001b). Preliminary investigations, obtained by V.G. Bakhmutov in 2006 and ongoing study of Stari Kaydaky profile cannot indicate evidence of the MBB boundary at least above $\mathrm{sh}_{1}$ subunit (Fig. 4).

The Medzhybizh-A section and the lowermost part of the Holovchyntsi-1 section from Podolia region are characterized by low concentration of ferrimagnetic material, the destruction of the primary sedimentary magnetic texture, which makes them unsuitable for qualitative magnetostratigraphic studies. Additionally, the Medzhybizh-A section has very small thickness of stratigraphic units (Fig. 4). A zone of normal polarity, probably the Brunhes chron, has been reliably determined in the uppermost part of the Holovchyntsi-1 section ( $\mathrm{sh}_{3}$ subunit). The palaeomagnetic veracity of the remaining investigated layers is questioned. Unfortunately, reliable data on the MBB and, correspondingly, data on the age of any layers with artifacts in the Medzhybizh-A and the Holovchyntsi-1 sections more than $780 \mathrm{kyr}$ have not been obtained from the results of palaeomagnetic studies.

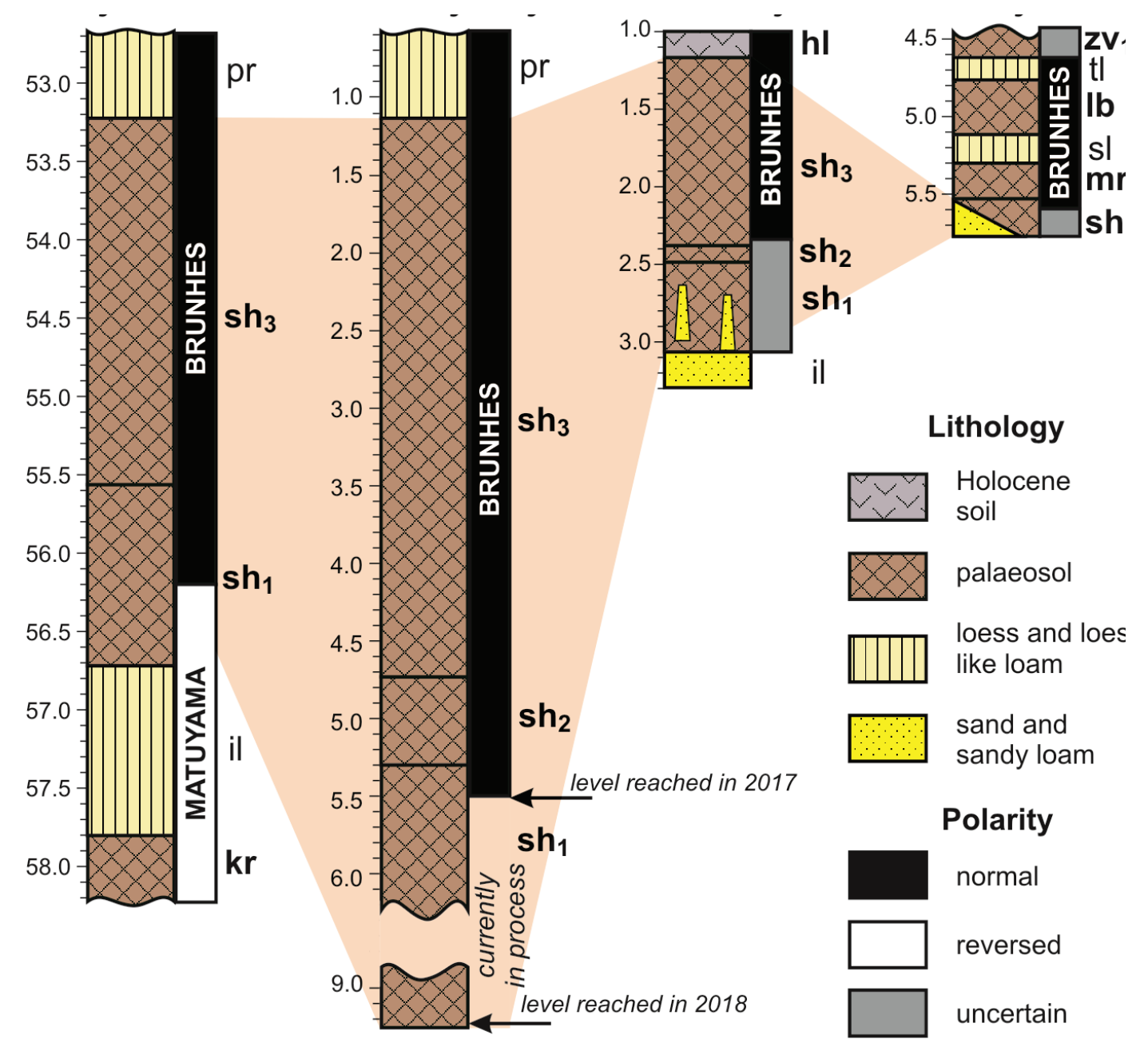

Fig. 4. Comparison chart of Shyrokyne palaeosol complex in the Vyazivok, Stari Kaydaky, Holovchyntsi and Medzhybizh sections. 
These results further supports that the Shyrokyne palaeosol unit should be comparable to the marine oxygen isotope stage 19 (as well as in (Bogucki et al., 2012)) rather than 25 (Veklich, 1995, cited in Bolikhovskaya and Molodkov, 2006) or 21-33 (Lindner et al., 2006).

Inconsistencies in the stratigraphic position of the MBB in the Shyrokyne and Martonosha units relative to the national stratigraphic scheme (Veklich et al., 1993) in different studies could be caused by following factors: 1) ambiguous physical definition of the palaeoclimatic boundaries; 2) the relatively low sampling resolution of some previous studies; 3 ) methodological difficulties in determination of the ChRM component; 4) inconsistent or incorrect stratigraphic subdivisions of Pleistocene loess-palaeosol series in some studies. They are not evidently associated with the influence of secondary magnetization processes on the palaeomagnetic record because of a huge distance between the Shyrokyne and Martonosha units in the Middle Dnieper sequences (3-13 m). Even for thick Chinese loess sequences lock-in effect exceed not more 2-3 m (Tauxe et al., 1996; Zhou and Shackleton, 1999; Spassov et al., 2003; Liu et al., 2008). Since the MBB was defined in loess series of Ukraine much more often in palaeosol, it should be stratigraphically the same horizon.

Furthermore, the determination of the position of the MBB in loess sections should take into account the fact that loess sediments are affected by soil formation processes less than compared to soils (Bolshakov, 2008). Therefore, the overprinting effect of chemical magnetization in loess is less significant. Thus, loess can serve as a barrier against palaeomagnetic lock-in depth due to secondary chemical processes. In other words, if the Matuyama-Brunhes reversal is synchronous with the formation of a part of soil horizon, the palaeomagnetic record of the reversal in general cannot be displaced appreciably below the boundary between the soil and underlying loess (Bolshakov, 2008). The Pryazovya loess unit below the Martonosha unit in the Vyazivok and Stari Kaydaky sections has completely normal polarity, which excludes secondary processes overprint on the palaeomagnetic record in above layers. Notably, in earlier works (Veklich, 1982; Veklich, 1987), in which the MBB had been placed in the Martonosha unit, the entire underlying Pryazovya loess has normal polarity and it was mistakenly attributed to Jaramillo excursion.

Magnetic and palaeomagnetic characteristics of the key sections of the Ukrainian loess sequences composed of various types of loess-palaeosol horizons should be carefully studied and an integrated palaeogeographic analysis of the sediments should be conducted in order to compare climatic conditions of the formation of loess and soil units located around the MBB in different sequences. Clarifying the question of stratigraphic position of the MBB in key loess series of Ukraine allows recognizing the most objective chronostratigraphic marker and would help to correlate them with other loess sequences across Eurasia.

\section{Conclussions.}

Using multiple tools of measurements in different palaeomagnetic laboratories, the MBB was identified in the Vyazivok section at the Shyrokyne lowermost palaeosol sh $\mathrm{sh}_{1}$ subunit.

In the Stari Kaydaky section the MBB cannot be defined at least above Shyrokyne sh ${ }_{1}$ subunit. Further study is currently in progress to identify polarity reversal in underlying layers.

Among studied sections in Podolian Upland only the uppermost part of the Holovchyntsi section (subhorizon $\mathrm{sh}_{3}$ ) has been turned out to be acceptable for palaeomagnetic studies, in which the Brunhes chron of normal polarity has been reliably determined. The palaeomagnetic informativeness of the rest of the studied strata is questionable.

In the present Ukrainian stratigraphic system the chronological setting of the Shyrokyne and Martonosha units is regarded in different ways. It appears most reasonable (at least in studied sequences) to correlate the Shyrokyne complex with MIS 19, and the Martonosha unit with MIS 17. This correlation supports the stratigraphic model of (Bogucki et al., 2012).

Acknowledgements. This research was supported by grant 0117 U003498 from National Academy of Sciences of Ukraine. The author wishes to thank D.Sc. N.P. Gerasimenko, D.Sc. Zh.M. Matviishyna, D.Sc. V.M. Stepanchuk and PhD S.P. Karmazinenko for their assistance during field works.

\section{References}

Bakhmutov, V., Hlavatskyi, D., Stepanchuk, V., Poliachenko, Ie., 2018. Rock magnetism and magnetostratigraphy of loess-palaesol sections - Lower Paleolithic sites of Podolian Upland (Medzhybizh, Holovchintsi). 12th International Conference on Monitoring of Geological Processes and Ecological Condition of the Environment. Kyiv.

Bakhmutov, V.G., Hlavatskyi, D.V., 2014a. Opredelenie granicy Matujama-Brjunes po rezul'tatam paleomagnitnyh issledovanij razreza Roksolany (zapadnoe Prichernomor'e) [Identification of the Matuyama-Brunhes boundary by paleomagnetic studies of the Roxolany profile (Western Black Sea 
region)]. Dopov. Nac. akad. nauk Ukr. 10, 92-98 (in Russian).

Bakhmutov, V.G., Hlavatskyi, D.V., 2014b. Novye dannye po granice Matujama-Brjunes v razreze Roksolany [New data about Matuyama-Brunhes boundary in Roxolany section]. Geologichniy zhurnal. 2 (347), 73-84 (in Russian).

Bakhmutov, V.G., Hlavatskyi, D.V., 2016. Problemy magnitostratigrafii plejstocenovyh lessovopochvennyh otlozhenij juga Ukrainy [Problems of magnetostratigraphy of Pleistocene loess-soil deposits in the South of Ukraine]. Geofizicheskiy zhurnal. 4 (38), 59-75 (in Russian).

Bakhmutov, V.G., Kazanskii, A.Yu., Matasova, G.G., Glavatskii, D.V., 2017. Rock magnetism and magnetostratigraphy of the loess-sol series of Ukraine (Roksolany, Boyanychi, and Korshev Sections). Izv. Phys. Solid Earth. 53 (6), 65-86.

Bakhmutov, V.G., Mokriak, I.N., Skarboviychuk, T.V., Yakukhno, V.I., 2005. Rezul'taty paleomagnitnyh issledovanij razreza dunajskih terras i problem magnitostratigrafii plejstocena Zapadnogo Prichernomor'ja [Results of palaeomagnetic studies of Danube terraces sections and problems of Pleistocene magnetostratigraphy of the west Black Sea region]. Geofizicheskiy zhurnal. 6 (25), 980-991 (in Russian).

Bogucki, A., Łanczont, M., Gozhik, P., Komar, M., 2013. Lesovyi rozriz Roksolany: roztashuvannia, istoriia doslidzhen, kharakterystyka vidkladiv [Roksolany loess section: location, research history, characteristic of sediments]. In: Bogucki, A. (Ed.). Loess cover of the Northern Black Sea. Proceeding of the XVIII Ukr.-pol. Workshop 8-13 Sept. 2013. KARTPOL s. c., Lublin. 47-58 (in Ukrainian).

Bogucki, A., Łanczont, M., Tomeniuk, O., Sytnyk, O., 2012. Deliuvialno-solifliuktsiini protsesy i problemy perevidkladennia i datuvannia paleolitychnykh kulturnykh horyzontiv [Delluvial-solifluctional processes and problems of redeposition and dating of palaeolithic cultural horizons]. Materialy i doslidzhennia z arkheolohii Prykarpattia i Volyni. 16. 55-64 (in Ukrainian).

Bolikhovskaya, N.S., Molodkov, A.N., 2006. East European loess-palaeosol sequences: Palynology, stratigraphy and correlation. Quaternary International. 149, 24-36.

Bolshakov, V.A., 2008. On the paleomagnetism of loesses and correlation of the Belovo and Volodarka sections (the Ob River Region). Izvestiya, Physics of the Solid Earth. 7 (44), 593-602.

Buggle, B., 2011. Reconstruction of the Late and MidPleistocene climate and landscape history in SECentral Europe. Doctoral thesis, University of Bayreuth. 343 pp.

Buggle, B., Glaser, B., Zöller, L., Hambach, U., Marković, S., Glaser, I., Gerasimenko, N., 2008. Geochemical characterization and origin of Southeastern and
Eastern European loesses (Serbia, Romania, Ukraine). Quaternary Science Reviews. 9-10 (27), 1058-1075.

Buggle, B., Hambach, B., Glaser, B., Gerasimenko, N., Marković, S., Glaser, I., Zöller, L., 2009. Stratigraphy, and spatial and temporal paleoclimatic trends in Southeastern/Eastern European loess-paleosol sequences. Quaternary International. 1-2 (196), 86-106.

Chadima, M., Hrouda, F. 2006. Remasoft 3.0 a userfriendly paleomagnetic data browser and analyzer. Travaux Geophysiques. XXVII, 20-21.

Evans, M., Heller, F., 2003. Environmental Magnetism. Principles and Applications of Enviromagnetics. Academic Press, Elsevier Science. 295 pp.

Gozhik, P., Gerasimenko, N., 2011. The lower and middle Pleistocene of Ukraine. In: Gozhik, P. (Ed.). Quaternary studies in Ukraine. Kyiv. 9-26.

Gozhik, P., Komar, M., Krokhmal, O., Shovkoplias, V., Khrystoforova, T., Dykan, N., Prylypko, S., 2007. Opornyi rozriz neopleistocenovykh subaeralnykh vidkladiv bilia s. Roksolany (Odeska oblast) [The key section of Neopleistocene subaerial deposits near Roxolany village (Odessa region)]. In: Problemy serednoplejstocenogo interglacialu. Lviv, Vid. Centr LNU im. I. Franka. 109-128 (in Ukrainian).

Hlavatskyi, D., Bakhmutov, V., Bogucki, A., Voloshyn, P., 2016a. Petromahnetyzm i paleomahnetyzm subaeralnykh vidkladiv rozriziv Boianychi i Korshiv (Volynska vysochyna) [Petromagnetism and paleomagnetism of subaerial deposits of Boyanychi and Korshiv sections (Volhynian Upland)]. Visnyk of Taras Shevchenko National University of Kyiv: Geology. 1 (72), 43-51 (in Ukrainian).

Hlavatskyi, D.V., Kuzina, D.M., Gerasimenko, N.P., Bakhmutov, V.G., 2016b. Petromagnetizm i paleomagnetizm chetvertichnyh lessovopochvennyh otlozhenij razreza Vjazovok (Pridneprovskaja nizmennost') [Petromagnetism and paleomagnetism of Quarternary loesssoil sediments of Vyazovok section (Dnieper Lowland)]. Geofizicheskiy zhurnal. 6 (38), 186193 (in Russian).

Kirschvink, J.L., 1980. The least squares line and plane and the analysis of palaeomagnetic data. Geophys. J. Roy. Astron. Soc. 62, 699-718.

Lindner L., Gozhik P., Marciniak B., Marks L., Yelovicheva Y., 2004. Main climatic changes in the Quaternary of Poland, Belarus and Ukraine. Geological Quarterly. 48 (2), 97-114.

Lindner, L., Bogutsky, A., Gozhik, P., Marks, L., Łanczont, M., Wojtanowicz, J., 2006. Correlation of Pleistocene deposits in the area between the Baltic and Black Sea, Central Europe. Geological Quarterly. 50 (1). 195-210.

Liu, Q., Roberts, A.P., Rohling, E.J., Zhu, R., Sun, Y., 2008. Post-depositional remanent magnetization lock- 
in and the location of the Matuyama-Brunhes geomagnetic reversal boundary in marine and Chinese loess sequences. Earth and Planetary Science Letters. 275, 102-110.

Man, O., 2008. On the identification of magnetostratigraphic polarity zones. Studia Geophysica at Geodaetica. 52. 173-186.

Matviishina, Zh., Mel'nichuk, I., Perederyi, V., Gerasimenko, N., 2001. Vyazivok section. In: The Ukraine Quaternary explored. Excursion guide of the SEQS 2001 conference, Ukraine. 23-36.

Matviishina, Zh.M., Gerasimenko, N.P., Perederyi, V.I., Bragin, A.M., Ivchenko, A.S., Karmazinenko, S.P., Nagirnyi, V.M., Parkhomenko, O.G., 2010. Prostorovo-chasova koreliatsiia paleoheohrafichnykh umov chetvertynnoho periodu na terytorii Ukrainy [Spatio-temporal correlation of Quaternary palaeogeographic conditions on the territory of Ukraine]. Naukova dumka, Kyiv. 191 pp. (in Ukrainian).

Rousseau, D.-D., Gerasimenko, N., Matviischina, Zh., Kukla, G., 2001. Late Pleistocene Environments of the Central Ukraine. Quaternary Research. 56, 349-356.

Sirenko, O., 2017. Subaeralni vidklady eopleistotsenunyzhnoho neopleistotsenu rivnynnoi chastyny Ukrainy ta yikh palinolohichna kharakterystyka [Subaeral Eopleistocene-Lower Neopleistocene deposits of the plain part of Ukraine and their palynological characteristic]. Dnipropetrovsk University Bulletin. Series: geology, geography. 25 (1), 101-118 (in Ukrainian).

Slivinskaya, G.V., Skarboviychuk, T.V., Yakukhno, V.I., Kniazkova, I.L., 2012. Rezul'taty paleomagnitnyh issledovanij plejstocenovyh otlozhenij Priazov'ja (razrez Botievo) [Results of palaeomagnetic studies of Pleistocene deposits of Pryazovye (Botievo section)] Geofizicheskiy zhurnal. 6 (34), 79-90 (in Russian).

Spassov, S., Heller, F., Evans, M.E., Yue, L.P., von Dobeneck, T., 2003. A lock-in model for the complex Matuyama-Brunhes boundary record of the loess/palaeosol sequence at Lingtai (Central Chinese Loess Plateau). Geophys. J. Int. 155, 350-366.

Stepanchuk, V.N., Ryzhov, S.N., Matvyyshyna, Zh.N., 2014. Pervye itogi izucheniya nizhne-paleoliticheskikh mestonakhozhdenyy Medzhybozha [The first results of the study of the Lower Paleolithic locations of Medzhibozh]. Mistseznakhodzhennya Medzhybizh i problemy vyvchennya nyzhn'oho paleolitu Skhidnoyevropeys'koyi rivnyny. 22-48 (in Russian).

Stepanchuk, V.N., Veklych, Yu.M., Vetrov, V.S., Karmazynenko, S.P., Komar, M.S., Pohorelets, O.H. (2016). Otchet o rabotakh 2015 g. bliz pht Medzhibozh Letichevskoho r-na Khmel'nytskoy oblasty [Report on works in 2015 near Medzhibozh town of Letichev district of Khmelnytska Oblast].
Kyiv, Institute of Archaeology of NAS Ukraine. 82 pp. (in Russian).

Sirenko, O.A. Bakhmutov, V.G., Nikitchenko, I.M., 2008. Novi materiali do vivchennja neoplejstocenovih vidkladiv pozal'odovikovoï zoni Ukraïns'kogo shhita [New data for studing Neopleistocene deposits of Nonglacial zone of the Ukrainian Shield]. Geologichnij zhurnal. 4 (325). 113-122 (in Ukrainian).

Tauxe, L., Herbert, T., Shackleton, N.J., Kok, Y.S., 1996. Astronomical calibration of the MatuyamaBrunhes boundary: consequences for magnetic remanence acquisition in marine carbonates and the Asian loess sequences. Earth Planet. Sci. Lett. 140, 133-146.

Treatyak, A.N. Vigilyanskaya, L.I., 1994. Magnitostratigraficheskaja shkala plejstocena Ukrainy [Magnetostratigraphic scale of Pleistocene of Ukraine]. Geofizicheskiy zhurnal. 2 (16), 3-14 (in Russian).

Treatyak, A.N. Vigilyanskaya, L.I., Makarenko, V.N., Dudkin, V.P., 1989. Tonkaja struktura geomagnitnogo polja v pozdnem kajnozoe [Thin structure of geomagnetic field in Late Cenozoic]. Kiev: Nauk. Dumka, 156 pp. (in Russian).

Treatyak, A.N., 1983. Estestvennaja ostatochnaja namagnichennost' i problema paleomagnitnoj stratifikacii osadochnyh tolshh [Natural remnant magnetization and problem of sediments paleomagnetic stratification]. Nauk Dumka, Kyiv. 256 pp. (in Russian).

Tretyak, A.N., 1980. Rezhim geomagnitnogo polja V plejstocene i struktura geomagnitnoj epohi Brjunes [Regim of the Pleistocene geomagnetic field and structure of the Brunhes geomagnetic epoch]. Geofizicheskiy zhurnal. 5 (2). 75-87 (in Russian).

Tretyak, A.N., Dudkin, V.P., Vigilyanskaya, L.I., 1980. Zakonomernosti izmenenija geomagnitnogo polja $\mathrm{v}$ pliocen-chetvertichnoe vremja. [Patterns of changes in the geomagnetic field during the Pliocene-Quaternary]. Preprint. Institute of Geophysics of AS USSR, Kiev. 189 pp. (in Russian).

Tretyak, A.N., Dudkin, V.P., Vigilyanskaya, L.I., 1986. Izuchenie dinamiki magnitnogo polja Zemli i voprosy paleomagnitnoj stratigrafii [Studying the dynamics of the Earth's magnetic field and issues of paleomagnetic stratigraphy]. Geofizicheskiy zhurnal. 1 (8). 28-33 (in Russian).

Tretyak, A.N., Shevchenko, A.I., Dudkin, V.P., Vigilyanskaya, L.I., 1987. Paleomagnitnaja stratigrafija opornyh razrezov pozdnego kajnozoja juga Ukrainy [Paleomagnetic stratigraphy of key Late Cenozoic sections of the south of Ukraine]. Preprint. Institute of Geological Sciences of AS USSR, Kiev. 50 pp. (in Russian).

Tretyak, A.N., Volok, Z.E., 1976. Paleomagnitnaya stratigrafiya pliotsen-chetvertichnykh osadochnykh tolshch Ukrainy [Paleomagnetic 
stratigraphy of Pliocene and Quaternary sediments in Ukraine). Naukova Dumka, Kiev (in Russian)

Veklich, M.F., 1982. Paleojetapnost' i stratotipy pochvennyh formacij verhnego kajnozoja Ukrainy [Paleostages and stratotypes of soil formations of the Upper Cenozoic]. Naukova Dumka, Kiev. 202 pp. (in Russian).

Veklich, M.F., 1987. Problemmy paleoklimatologii [Problems of palaeoclimatology]. Naukova dumka, Kyiv. 190 pp. (in Russian).

Veklich, M.F., Artyushenko, A.T., Sirenko, N.A., Dubnyak, V.A., Mel'nichuk, I.V., and Parishkura, S.I., 1967. Opornye razrezy antropogena Ukrainy [Key Sections of the Anthropogene of Ukraine]. Naukova Dumka, Kiev. 13-50 (in Russian).

Veklich, M.F., Sirenko N.A., 1972. Opornye geologicheskie razrezy antropogena Ukrainy. Ch.3[Key Sections of the Anthropogene of Ukraine. Part III]. Naukova Dumka, Kiev. 225 pp. (in Russian).

Veklich, M.F., Sirenko, N.A., Matviishina, Z.N., Gerasimenko, N.P., Perederij, V.I., Turlo, S.I., 1993. Stratigraficheskie shemy chetvertichnyh otlozhenij Ukrainy [Stratigraphical Schemes of the Quaternary Deposits of Ukraine]. Goskomgeologia of Ukraine, Kiev. Explanatory notes (in Russian).

Veklich, M.F., Sirenko, N.A., Matviyishina, Zh.N., 1984. Paleogeograficheskie etapy i detal'noe stratigraficheskoe raschlenenie plejstocena Ukrainy [Paleographic phases and detail stratigraphic partition of Pleistocene of Ukraine]. Naukova Dumka, Kiev. 32 pp. (in Russian).

Vetrov, V.S., 2016. Otchet ob issledovanii nizhnepaleoliticheskogo mestonahozhdenija Golovchincy-1 v 2016 [Report on the study of the Lower Paleolithic site Golovchintsy-1]. Kyiv, Institute of Archaeology of NAS Ukraine. 63 pp. (in Russian).

Vigilyanskaya, L.I., 2001a. Magnetostratigraphy of Pliocene-Pleistocene sediments of the Middle near-Dnieper region. The Ukraine Quaternary explored: the Middle and Upper Pleistocene of the Middle Dnieper area and its importance for the East-West European correlation. Abstracts of the SEQS 2001 conference. Kyiv. 98.

Vigilyanskaya, L.I., 2001b. Paleomagnetic section and magnetic properties of Quaternary deposits of the Viazivok site. In: The Ukraine Quaternary explored. Volume of abstracts. Kyiv. 97.

Vigilyanskaya, L.I., Tretyak, A.N., 2000. Paleomagnetizm opornyh razrezov pliocen-plejstocenovyh otlozhenij severo-zapadnogo Donbassa [Palaeomagnetism of key Pliocene-Pleistocene sections in North-Western Donbass]. Geofizicheskiy zhurnal. 3 (22). 96-104 (in Russian).

Vigilyanskaya, L.I., Tretyak, A.N., 2002. Paleomagnintye issledovanija pliocen-plejstocenovyh otlozhenij lessovo-pochvennoj formacii Srednego Pridneprov'ja [Palaeomagnetic studies of Pliocene-Pleistocene deposits of loess-palaeosol stratum in Middle Dnieper region]. Geofizicheskiy zhurnal. 5 (24). 36-42 (in Russian).

Zhou, L.P., Shackleton, N.J., 1999. Misleading positions of geomagnetic reversal boundaries in Eurasian loess and implications for correlation between continental and marine sediment sequences, Earth planet. Sci. Lett. 168, 117-130. 